\title{
Hypoxia Modulates Cholinergic but Not Opioid Activation of $G$ Proteins in Rat Hippocampus
}

\author{
V.S. Hambrecht, ${ }^{1}$ P.E. Vlisides ${ }^{1}$ B.W. Row ${ }^{2}$ D. Gozal, ${ }^{2}$ H.A. Baghdoyan, ${ }^{1}$ and R. Lydic $^{1 *}$
}

\begin{abstract}
Intermittent hypoxia, such as that associated with obstructive sleep apnea, can cause neuronal death and neurobehavioral dysfunction. The cellular and molecular mechanisms through which hypoxia alter hippocampal function are incompletely understood. This study used in vitro $\left[{ }^{35} \mathrm{~S}\right]$ guanylyl-5'-O-( $\gamma$-thio)-triphosphate $\left(\left[{ }^{35} \mathrm{~S}\right] \mathrm{GTP} \gamma \mathrm{S}\right)$ autoradiography to test the hypothesis that carbachol and DAMGO activate hippocampal $\mathrm{G}$ proteins. In addition, this study tested the hypothesis that in vivo exposure to different oxygen $\left(\mathrm{O}_{2}\right)$ concentrations causes a differential activation of $G$ proteins in the CA1, CA3, and dentate gyrus (DG) regions of the hippocampus. $G$ protein activation was quantified as $\mathrm{nCi} / \mathrm{g}$ tissue in CA1, CA3, and DG from rats housed for 14 days under one of three different oxygen conditions: normoxic $\left(21 \% \mathrm{O}_{2}\right)$ room air, or hypoxia $\left(10 \% \mathrm{O}_{2}\right)$ that was intermittent or sustained. Across all regions of the hippocampus, activation of $G$ proteins by the cholinergic agonist carbachol and the mu opioid agonist [D-Ala ${ }^{2}, \mathrm{~N}$ Met-Phe ${ }^{4}$, Gly $^{5}$ ] enkephalin (DAMGO) was ordered by the degree of hypoxia such that sustained hypoxia $>$ intermittent hypoxia $>$ room air. Carbachol increased G protein activation during sustained hypoxia $(38 \%)$, intermittent hypoxia $(29 \%)$, and room air $(27 \%)$. DAMGO also activated $G$ proteins during sustained hypoxia $(52 \%)$, intermittent hypoxia $(48 \%)$, and room air $(43 \%)$. Region-specific comparisons of $G$ protein activation revealed that the DG showed significantly less activation by carbachol following intermittent hypoxia and sustained hypoxia than the CA1. Considered together, the results suggest the potential for hypoxia to alter hippocampal function by blunting the cholinergic activation of $G$ proteins within the DG. $\odot 2007$ Wiley-Liss, Inc.
\end{abstract}

KEY WORDS: acetylcholine; neurobehavioral impairment; sleep apnea

\section{INTRODUCTION}

Obstructive sleep apnea (OSA) is characterized by repeated obstruction of the upper airway during sleep and results in episodes of intermittent hypoxia and sleep fragmentation (Ryan and Bradley, 2005). An estimated 12-18 million people in the United States have sleep apnea, with a higher prevalence in men $(4 \%)$ than in women $(2 \%)$ and OSA is associated with risk factors such as age, excessive weight, and high blood pressure (Young et al., 1993). In OSA patients, hypoxic events can occur

\footnotetext{
${ }^{1}$ Department of Anesthesiology, University of Michigan, Ann Arbor, Michigan; ${ }^{2}$ Department of Pediatrics, Kosair Children's Hospital Research Institute, University of Louisville, Louisville, Kentucky Grant sponsor: National Institutes of Health; Grant numbers: HL40881, HL57120, HL65272, MH45361, HL69932, 2P50HL60296.

*Correspondence to: Ralph Lydic, Ph.D., Department of Anesthesiology, University of Michigan, 7433 Medical Sciences Bldg. I, 1150 W Medical Center Drive, Ann Arbor, MI 48109-0615, USA. E-mail: rlydic@umich.edu Accepted for publication 18 April 2007

DOI 10.1002/hipo.20312

Published online 27 June 2007 in Wiley InterScience (www.interscience. wiley.com).
}

20-30 times per hour with cessation of breathing lasting for 10-20 s or more (Shamsuzzaman et al., 2003). Daytime symptoms of OSA include excessive sleepiness and neurobehavioral impairment (Engleman and Joffe, 1999; Beebe, 2005; Walker and Stickgold, 2006). Research concerning the effects of intermittent hypoxia has been stimulated by efforts to understand the impact of hypoxia on sleep, learning, and memory (Ninomiya et al., 1989; Greenberg et al., 1999; Gozal et al., 2001a; Hamrahi et al., 2001; Gozal et al., 2002; Goldbart et al., 2003a,b; Row et al., 2003; Zhao et al., 2005).

The hippocampus is vulnerable to hypoxia (Yamaoka et al., 1993; Matsuoka et al., 1997; Gozal et al., 2001a,b) and intermittent hypoxia alters the excitability of hippocampal neurons (Schiff and Somjen, 1985). Cholinergic neurotransmission contributes to hippocampal function (Colom et al., 1991), and muscarinic cholinergic receptors are expressed by hippocampal neurons (Satoh and Kaneko, 1994; Rouse et al., 1999; van der Zee and Luiten, 1999). Muscarinic cholinergic receptors are $G$ protein coupled (reviewed in Caulfield and Birdsall, 1998), and carbachol activates muscarinic cholinergic receptors and $\mathrm{G}$ proteins in brain regions regulating sleep (Capece et al., 1998a; DeMarco et al., 2003; Douglas et al., 2004). Activated G proteins can be labeled using $\left[{ }^{35} \mathrm{~S}\right]$ guanylyl-5'-O-( $\gamma$-thio)-triphosphate $\left(\left[{ }^{35} \mathrm{~S}\right] \mathrm{GTP} \gamma \mathrm{S}\right)$ (Sim et al., 1995). The hippocampus also contains endogenous opioids (Watson et al., 1982) and mu opioid receptors (Crain et al., 1986; Mansour et al., 1987; Tempel and Zukin, 1987; Drake and Milner, 2002). Mu opioid receptors are coupled to $\mathrm{G}$ proteins (Corbett et al., 2006), providing a key rationale for the present use of the mu opioid receptor agonist [D-Ala $\left.{ }^{2}, \quad \mathrm{~N}-\mathrm{Met}-\mathrm{Phe}^{4}, \mathrm{Gly}^{5}\right] \quad$ enkephalin (DAMGO). G proteins in brain regions regulating sleep are activated by DAMGO (Capece et al., 1998b; Tanase et al., 2001; Bernard et al., 2006). Many studies have shown that activating mu opioid receptors can have excitatory actions throughout the hippocampus (Zieglgansberger et al., 1979; Dunwiddie et al., 1980; Siggins and Zieglgansberger, 1981; Mayer et al., 1994; Mayer and Henriksen, 1995). Hippocampal mu opioid receptors have a region-specific distribution and contribute to normal hippocampal function (Svodoba et al., 1999; Drake and Milner, 2002).

No previous studies have quantified the effect of hypoxia on cholinergic or opioid activation of $G$ proteins 

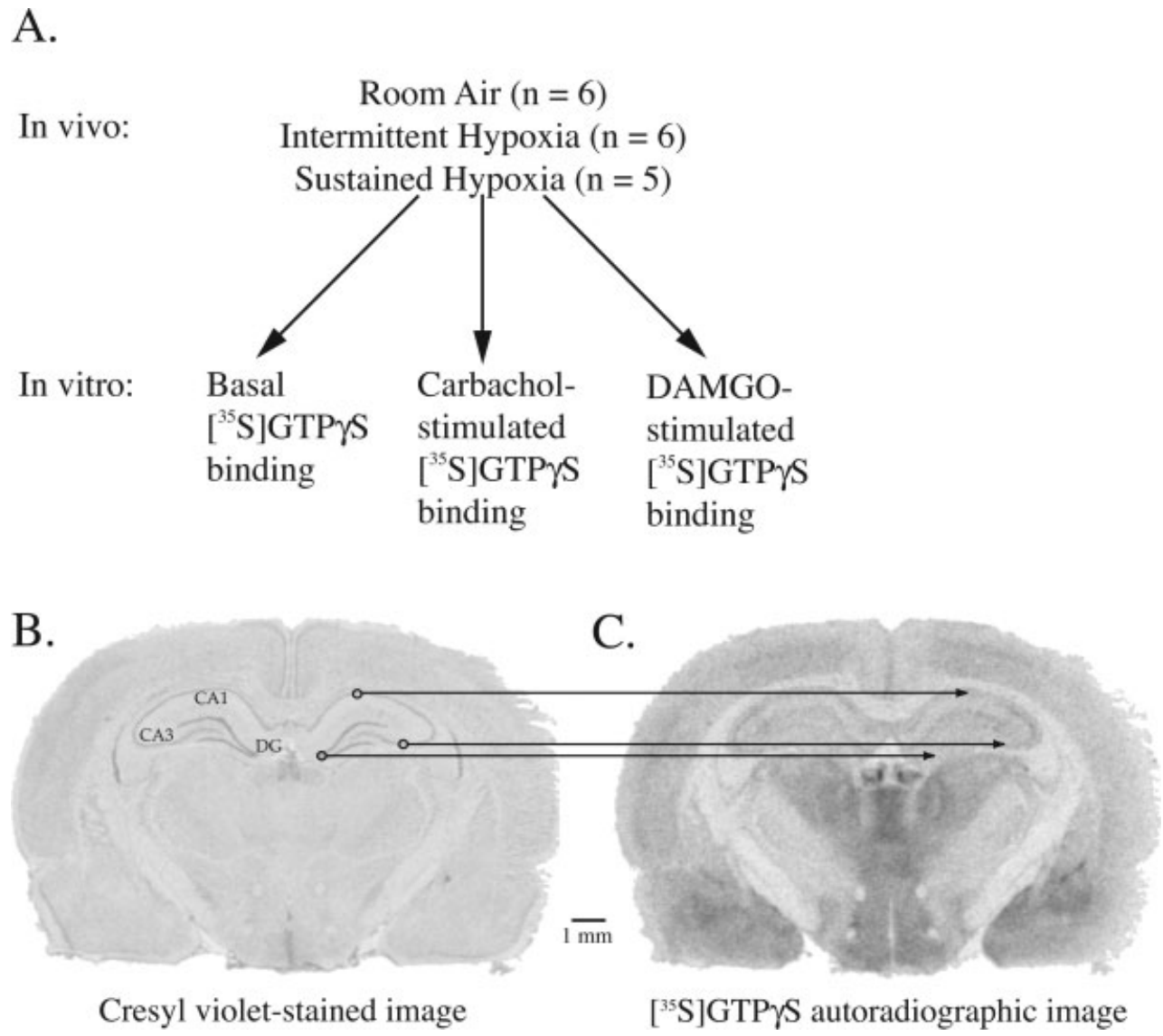

FIGURE 1. Schematic of study design and techniques used to quantify $G$ protein activation in the hippocampus. (A) Outlines the in vivo and in vitro phases of this study. During the initial in vivo phase, rats underwent one of the three treatments involving 14 days of exposure to room air, intermittent hypoxia, or sustained hypoxia. For the following in vitro phase of the study, rats were decapitated and brains were removed and immediately frozen. Brains were sectioned serially and the hippocampus was assayed for $G$ protein activation by the cholinergic agonist carbachol and the mu opioid receptor agonist DAMGO. Basal levels of $\left[{ }^{35} S\right]$ GTP $\gamma S$ binding (no agonist used) following 14 days of housing in room air served as the control condition. The number of

in rat hippocampus. Therefore, the present study was designed to test the hypothesis that carbachol and DAMGO activate hippocampal $\mathrm{G}$ proteins. In addition, this study tested the hypothesis that these changes in $\mathrm{G}$ protein activation are modulated by different hypoxic treatments (intermittent and sustained hypoxia) in the CA1, CA3, and dentate gyrus (DG) regions of the hippocampus. Portions of these results have been presented in abstract form (Hambrecht et al., 2006).

\section{MATERIALS AND METHODS}

\section{Overview of Study Design}

During 14 days of in vivo treatment, rats were exposed to either room air, intermittent hypoxia, or sustained hypoxia. On animals $(n)$ is shown for each in vivo condition. $(B, C)$ Schematic of the technique for obtaining region-specific measures of hippocampal $\left[{ }^{35} S\right]$ GTP $\gamma S$ binding. (B) Digitized image of a cresyl violet-stained tissue section containing hippocampal measurement sites. (C) Digitized image of an autoradiogram in which optical density in the hippocampus was proportional to $G$ protein activation quantified by the amount of $\left[{ }^{35} S\right] G T P \gamma S$ binding. The autoradiogram in (C) was created from the tissue section shown in (B). The circles on the hippocampus (B) indicate the locations that were transferred from the cresyl violet-stained section to the autoradiogram (C) for measuring $\left[{ }^{35} \mathrm{~S}\right] \mathrm{GTP} \gamma \mathrm{S}$ binding in $\mathrm{nCi} / \mathrm{g}$ tissue.

protocol day 15 , rats in all three groups were decapitated and brains were removed and frozen for a subsequent biochemical assay that makes it possible to quantify agonist-stimulated G protein activation in a brain region-specific manner (Sim et al., 1995, 1997; Harrison and Traynor, 2003). This in vitro assay (described below) focused on G proteins in the CA1, CA3, and DG regions of the hippocampus. Brain sections were assayed for $G$ protein activation using in vitro conditions that quantified basal, carbachol- and DAMGO-stimulated $\left[{ }^{35} \mathrm{~S}\right] \mathrm{GTP} \gamma \mathrm{S}$ binding. Figure $1 \mathrm{~A}$ provides a schematic overview of the study design.

\section{Animals and In Vivo Treatment}

All experiments were conducted in accordance with the Public Health Service policy on Humane Care and Use of 
Laboratory Animals (National Institutes of Health Publication 80-23). Before starting the experiment, groups of up to 6 adult male Sprague-Dawley rats (Charles River Laboratories, Wilmington, MA), 45-50 days old, were housed in identical chambers $(30 \times 20 \times 20$ cubic in) under normoxic conditions and in a 12:12 h light-dark cycle (lights on at 6:00 A.M.). Ambient temperature was maintained at $22-24^{\circ} \mathrm{C}$. Air circulation for each chamber was set at $60 \mathrm{~L} / \mathrm{min}$, resulting in one complete air turnover every $10 \mathrm{~s}$. To begin an experiment, rats were exposed for 14 days to one of three different $\mathrm{O}_{2}$ concentrations, as described previously (Gozal et al., 2001a). $\mathrm{O}_{2}$ concentration was monitored throughout the entire experiment and adjusted automatically if necessary. The intermittent hypoxia group $(n=6)$ experienced alternating $10 \% \mathrm{O}_{2}$ and $21 \% \mathrm{O}_{2}$ every $90 \mathrm{~s}$ for $12 \mathrm{~h}$ during the light phase, and room air for $12 \mathrm{~h}$ during the dark phase. Rats in the sustained hypoxia group $(n=5)$ were exposed to hypoxic air $\left(10 \% \mathrm{O}_{2}\right)$ throughout the $12 \mathrm{~h}$ of the light phase, and room air during the dark phase. Control animals $(n=6)$ were exposed to normoxic $\left(21 \% \mathrm{O}_{2}\right)$ room air $24 \mathrm{~h}$ per day. After 14 days animals were decapitated and brains were removed and frozen in a $-30^{\circ} \mathrm{C}$ bilayer of bromobutane (Fisher Scientific, Boston, MA) and isopentane (SigmaAldrich, St. Louis, MO) to prevent distortion. The favorable homology of this rodent model of sleep disordered breathing has been validated (Gozal et al., 2001a; Hamrahi et al., 2001).

\section{Tissue Preparation and In Vitro $\left[{ }^{35}\right.$ S GTP $\gamma$ S Autoradiography}

Coronal brain sections $(20 \mu \mathrm{m})$ that included the hippocampus (bregma -2.30 to $-4.30 \mathrm{~mm}$ ) (Paxinos and Watson, 1998) were cut serially using a Leica CM 3050 S cryostat (Leica Microsystems, Nussloch, Germany). Adjacent pairs of sections were thaw-mounted on gelatin-coated glass slides. The slides were dried in a vacuum desiccator $\left(4^{\circ} \mathrm{C}\right)$ and stored in a $-80^{\circ} \mathrm{C}$ freezer until used in the $\left[{ }^{35} \mathrm{~S}\right] \mathrm{GTP} \gamma \mathrm{S}$ assay.

Guanosine $5^{\prime}-O-(\gamma$-thio) triphosphate $(\mathrm{GTP} \gamma \mathrm{S})$, guanosine $5^{\prime}$-diphosphate (GDP), carbachol, DAMGO, and chemicals used for buffers were purchased from Sigma-Aldrich (St. Louis, MO). Perkin Elmer Life Science (Boston, MA) supplied the $\left[{ }^{35} \mathrm{~S}\right] \mathrm{GTP} \gamma \mathrm{S}$. Adenosine deaminase (ADA) was provided by Roche Applied Science (Indianapolis, IN). The $\left[{ }^{35} S\right]$ GTP $\gamma S$ binding assay was performed as previously described (DeMarco et al., 2003; Douglas et al., 2004). Slide mounted brain sections were removed from the freezer and slowly brought to room temperature. All tissue sections were rinsed in assay buffer ( $50 \mathrm{mM}$ Tris- $\mathrm{HCl}, 3 \mathrm{mM} \mathrm{MgCl}, 0.2 \mathrm{mM}$ EGTA, and $100 \mathrm{mM} \mathrm{NaCl}, \mathrm{pH}$ 7.4) for $10 \mathrm{~min}$. All sections were preincubated for $15 \mathrm{~min}$ in a solution containing assay buffer, $2 \mathrm{mM}$ GDP, and $2 \mathrm{U} / \mathrm{mg}$ ADA. One group of tissue sections was then incubated for $2 \mathrm{~h}$ in assay buffer containing $0.04 \mathrm{nM}$ $\left[{ }^{35} \mathrm{~S}\right] \mathrm{GTP} \gamma \mathrm{S}, 2 \mathrm{mM}$ GDP, $2 \mathrm{U} / \mathrm{mg} \mathrm{ADA}$, and the cholinergic agonist carbachol $(1 \mathrm{mM})$. Basal binding was measured in the absence of carbachol using a second group of tissue sections. A third set of tissue sections was incubated in assay buffer containing the mu opioid agonist DAMGO $(3 \mu \mathrm{M})$. Excess unlabeled GTP $\gamma S(10 \mu \mathrm{M})$ was used with a fourth group of brain sections to evaluate nonspecific binding. Incubation was terminated by rinsing the sections twice in ice-cold $50 \mathrm{mM}$ Tris$\mathrm{HCl}$ buffer ( $\mathrm{pH} 7.0$ ) for 2 min and once in deionized ice-cold water for $30 \mathrm{~s}$. Tissue sections then were dried at $4^{\circ} \mathrm{C}$ under a stream of air. Sections were placed in a vacuum desiccator at room temperature overnight to complete the drying process. Sections and ${ }^{14} \mathrm{C}$ microscale standards $(31-883 \mathrm{nCi} / \mathrm{g}$, Amersham Biosciences, Arlington Heights, IL) were packed in autoradiography cassettes containing Kodak BioMax MR film (Fisher Scientific, Boston, MA). The film was exposed for $16 \mathrm{~h}$ to the slide-mounted tissue sections and radioactive standards before being developed using a Kodak X-OMAT Model 2002A film processor. Tissue sections were fixed with paraformaldehyde vapor $\left(80^{\circ} \mathrm{C}\right)$ and stained with cresyl violet.

\section{Quantification of $\left[{ }^{35} \mathrm{~S}\right] \mathrm{GTP} \gamma \mathrm{S}$ Binding}

The assay described earlier produced autoradiographic images of hippocampal sections from each of the 17 brains studied. As a result of the exchange with GDP, the nonhydrolyzable $\left[{ }^{35} \mathrm{~S}\right] \mathrm{GTP} \gamma \mathrm{S}$ remained bound to the receptor-G protein complex. Thus, the increase in radioactivity and corresponding increase in optical density provided a quantitative index of $\mathrm{G}$ protein activation (Sim et al., 1995; Harrison and Traynor, 2003). The autoradiographic images and the cresyl violetstained tissue sections from which they were derived were digitized using a Cohu CCD camera with a Nikon $60 \mathrm{~mm}$ objective. The digitized images were analyzed using a G3 Macintosh computer running the Scion Image $1.62 \mathrm{c}$ version of the NIH Image program. Figures 1B,C illustrate the procedure for accurately localizing each hippocampal region (CA1, CA3, and DG) on a digitized image of a cresyl violet-stained tissue section. The $x-y$ coordinates of the localized region were then transferred to the corresponding autoradiographic image, from which the optical density measurements were made. These measurements represent total binding. Nonspecific binding values were obtained in the same manner. Specific $\left[{ }^{35} \mathrm{~S}\right] \mathrm{GTP} \gamma \mathrm{S}$ binding values were calculated by subtracting mean nonspecific binding values for each hippocampal region from the total binding values for that region. Specific $\left[{ }^{35} S\right]$ GTP $\gamma S$ binding values were expressed as $\mathrm{nCi} / \mathrm{g}$ tissue.

The present results summarize 9,180 data points of the type illustrated in Figure 1C. As previously described (Capece et al., 1998a; DeMarco et al., 2003; Douglas et al., 2004) the data were averaged to provide a mean for each animal, then averaged across animals for statistical comparisons. This statistically conservative approach circumvents issues of pseudo-replication and inflated degrees of freedom. The animal mean data were analyzed using repeated measures analysis of variance (ANOVA) and non-parametric Kruskal-Wallis test. Post-hoc comparisons were performed using Tukey-Kramer multiple comparisons test and $t$-test. A probability value of $P \leq 0.05$ was set as statistically significant. 


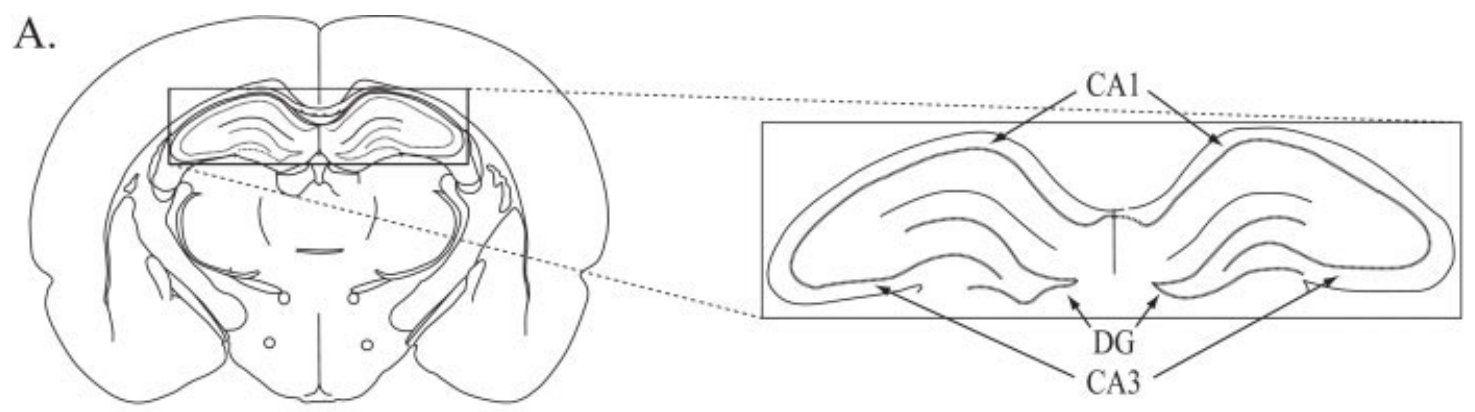

\section{B. Room Air}
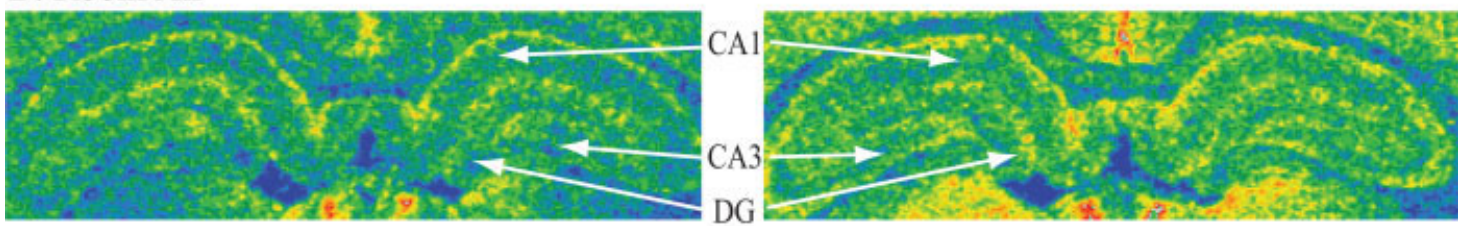

C. Intermittent Hypoxia
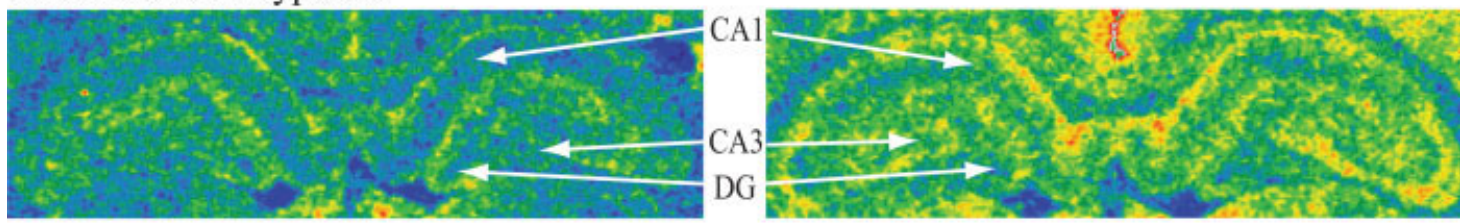

D. Sustained Hypoxia

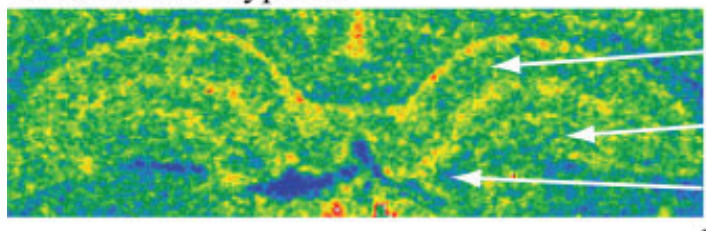

Basal

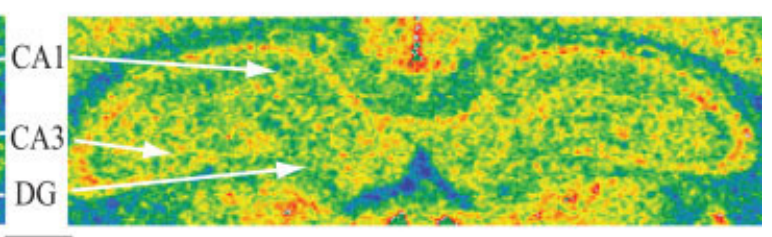

Carbachol

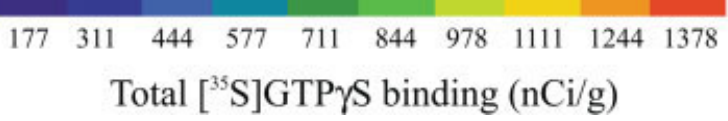

FIGURE 2. Carbachol activated $G$ proteins in the hippocampus. (A) Coronal atlas plate from Paxinos and Watson (1998) showing the three different measurement areas (CA1, CA3, and DG) in the rat hippocampus. The boxed area on the left is enlarged on the right to the same scale as the color-coded autoradiograms in (B), (C), and (D). Compared to basal levels of $\mathrm{G}$ protein activation, carbachol significantly activated $G$ proteins following room air (B), intermittent hypoxia (C), and sustained hypoxia (D) conditions.

\section{RESULTS}

\section{Cholinergic- and Opioid-Stimulated G Protein Activation}

Color-coded autoradiograms (Fig. 2) illustrate representative basal levels of hippocampal $G$ protein activation (left column) and $G$ protein activation caused by in vitro treatment with carbachol (right column). Comparing left and right columns of Figures $2 \mathrm{~B}-\mathrm{D}$ shows that the cholinergic agonist carbachol activated $\mathrm{G}$ proteins in all three hippocampal regions (CA1, CA3, and DG) obtained from rats exposed to the in vivo treatment conditions of room air, intermittent hypoxia, or sustained hypoxia. Levels of $\mathrm{G}$ protein activation illustrated by Figure 2 are expressed quantitatively in Figures 3 and 4 and described below.

Figures 3A-C summarize the effect of carbachol on $\left[{ }^{35} \mathrm{~S}\right]$ GTP $y S$ binding as a function of in vivo treatment condition for each hippocampal region. In the CA1 region (Fig. 3A) and the CA3 region (Fig. 3B) carbachol significantly $(P<0.01)$ increased $\left[{ }^{35} \mathrm{~S}\right] \mathrm{GTP} \gamma \mathrm{S}$ binding over basal binding values for the room air, intermittent hypoxia, and sustained hypoxia conditions. Figure 3C shows that within the DG carbachol caused 


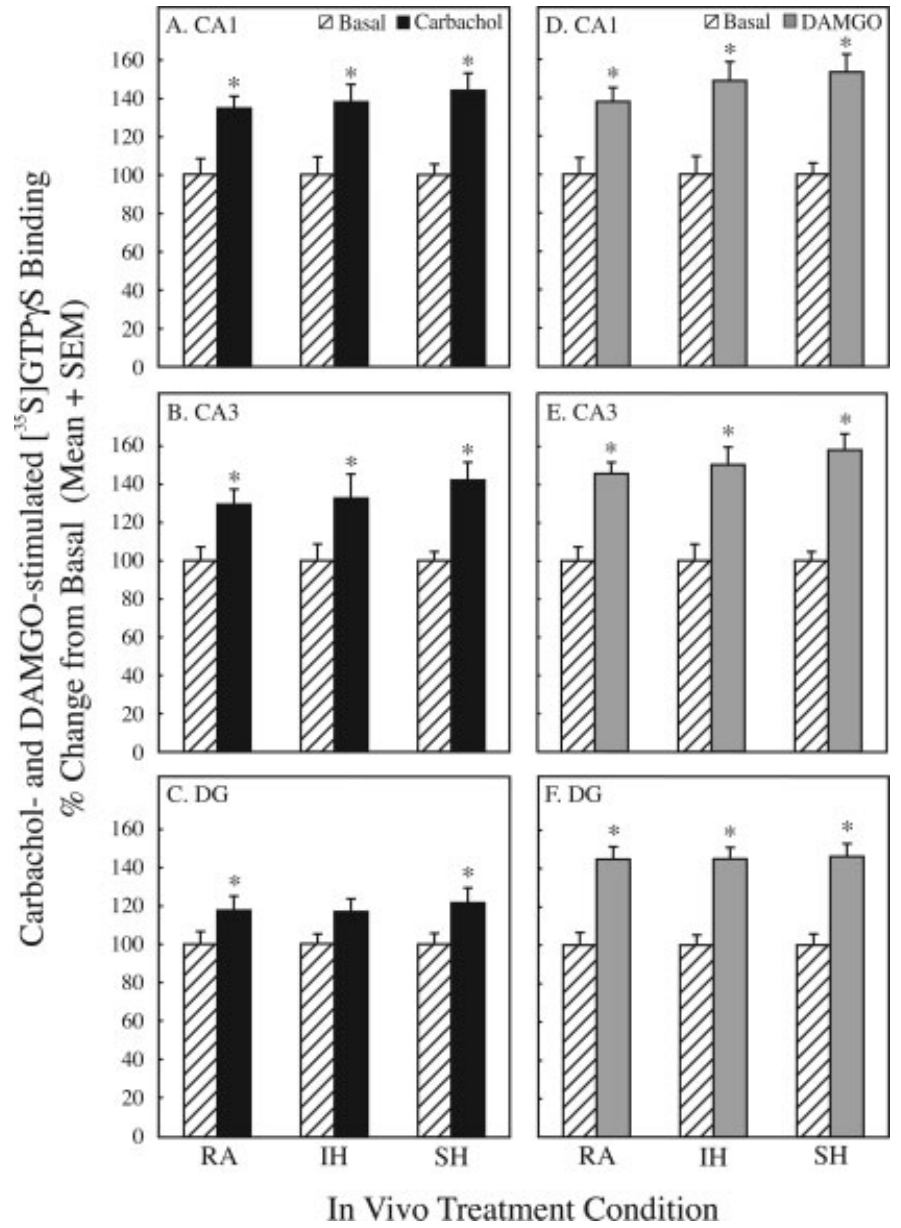

FIGURE 3. G protein activation in CA1, CA3, and DG as a function of exposure to room air (RA), intermittent hypoxia (IH), and sustained hypoxia (SH). (A) Relative to basal values (control), carbachol significantly $\left({ }^{*}\right)$ increased $\left[{ }^{35}\right.$ S] GTP $\gamma S$ binding in the CA1 region following all three in vivo conditions. (B) Carbachol-stimulated activation of $\mathrm{G}$ proteins in the $\mathrm{CA} 3$ was also significantly $\left(^{*}\right)$ increased compared to basal binding values for room air, intermittent hypoxia, and sustained hypoxia. (C) G protein activation by carbachol in the DG showed a significant $\left({ }^{*}\right)$ increase in room air and sustained hypoxia treated animals, but not for rats exposed to intermittent hypoxia. DAMGO significantly $\left({ }^{*}\right)$ increased $\left[{ }^{35}\right.$ S]GTP $\gamma S$ binding over basal binding values in the CA1, CA3, and DG (D-F) for all three in vivo treatments. Hippocampal $G$ proteins were significantly activated by carbachol and DAMGO, and ANOVA showed that there was no difference between any of the black bars (carbachol) and gray bars (DAMGO), respectively.

a significant $(P<0.01)$ increase in $\mathrm{G}$ protein activation for the room air and sustained hypoxia groups. In contrast, carbachol did not significantly increase $\left[{ }^{35} \mathrm{~S}\right] \mathrm{GTP} \gamma \mathrm{S}$ binding in the DG from rats exposed to intermittent hypoxia (Fig. 3C).

DAMGO caused a significant $(P<0.001)$ activation of hippocampal G proteins compared to basal levels (Figs. 3D-F). Furthermore, activation of $\mathrm{G}$ proteins by DAMGO was always greater than activation caused by carbachol. In contrast to carbachol, DAMGO significantly $(P<0.01)$ increased $\left[{ }^{35} \mathrm{~S}\right] \mathrm{GTP} \gamma \mathrm{S}$ binding in the DG for all three in vivo oxygen conditions (Fig. 3F). Comparison of $\left[{ }^{35} \mathrm{~S}\right] \mathrm{GTP} \gamma \mathrm{S}$ binding within each region of the hippocampus showed that carbacholand DAMGO-stimulated $\left[{ }^{35} \mathrm{~S}\right] \mathrm{GTP} \gamma \mathrm{S}$ binding did not significantly differ as a function of in vivo $\mathrm{O}_{2}$ condition.

\section{Activation of G Proteins in the CA1, CA3, and DG}

$\mathrm{G}$ protein activation by in vivo $\mathrm{O}_{2}$ condition and in vitro carbachol and DAMGO treatment is plotted in Figure 4 as a function of hippocampal region. For the room air-carbachol group (Fig. 4A), repeated measures one-way ANOVA showed no significant difference in $G$ protein activation as a function of hippocampal region. For animals treated with intermittent hypoxia (Fig. 4B), ANOVA revealed a significant difference in carbachol-stimulated $\mathrm{G}$ protein activation $(F=5.79 ; \mathrm{df}=2$, 12; $P=0.02$ ). Tukey-Kramer multiple comparisons test indicated that $\left[{ }^{35} \mathrm{~S}\right] \mathrm{GTP} \gamma \mathrm{S}$ binding was significantly lower in the DG than in the CA1. For the different hippocampal areas from the sustained hypoxia condition (Fig. 4C), ANOVA indicated a

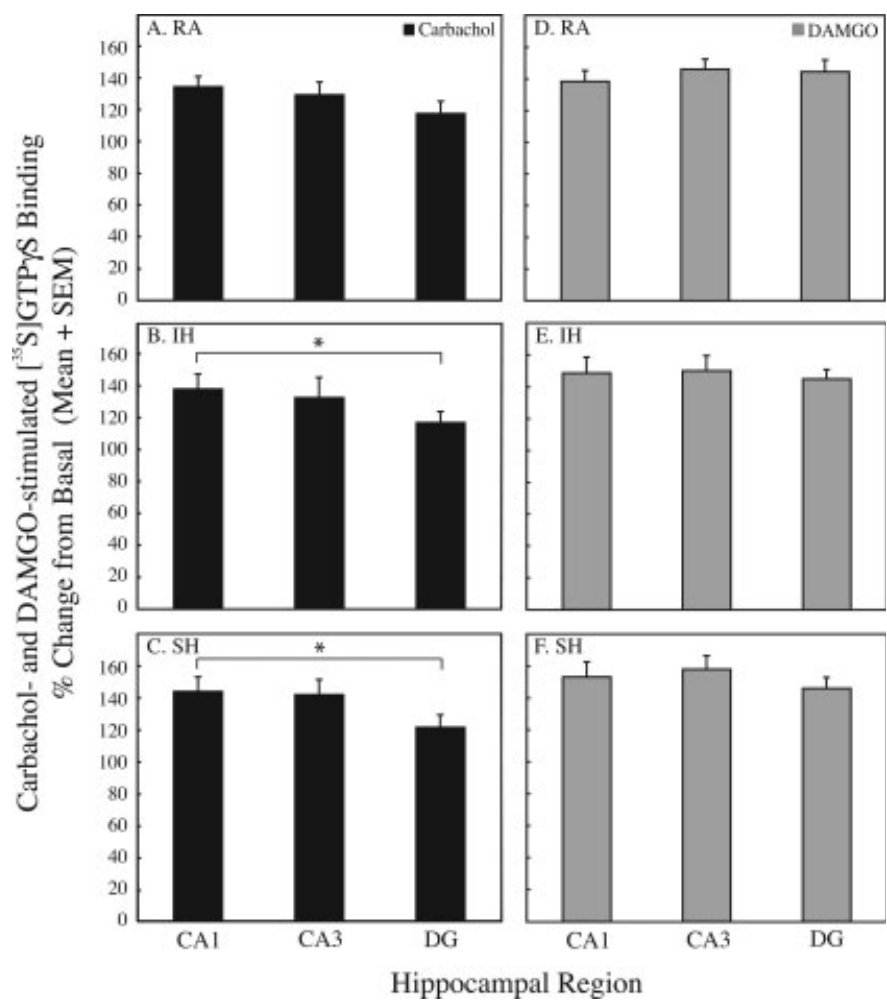

FIGURE 4. Carbachol- and DAMGO-stimulated G protein activation as a function of hippocampal region for each of the three in vivo treatment conditions. (A) Rats exposed to room air (RA) showed no significant differences in carbachol-stimulated $\left[{ }^{35}\right.$ S $]$ GTP $\gamma S$ binding levels between CA1, CA3, and DG. (B) Animals exposed to intermittent hypoxia $(\mathrm{IH})$ revealed significantly $\left(^{*}\right)$ lower G protein activation in the DG than in the CA1. (C) Rats exposed to sustained hypoxia $(\mathrm{SH})$ also displayed a significantly $\left(^{*}\right)$ lower activation of $G$ proteins in the DG than in the CA1 region. Common to all treatment conditions, the DG revealed a lower level of $G$ protein activation by carbachol. (D-F) DAMGO-stimulated $\left[{ }^{35} S\right]$ GTP $\gamma S$ binding showed no significant difference across hippocampal regions. Within CA1 and within DG carbachol activation of $G$ proteins varied as a function of hypoxic treatment. 
region-specific difference in $\mathrm{G}$ protein activation $(F=4.44$; $\mathrm{df}$ $=2,10 ; P=0.05)$. A significantly lower $\left[{ }^{35} \mathrm{~S}\right] \mathrm{GTP} \gamma \mathrm{S}$ binding level for DG compared to CA1 was confirmed by a TukeyKramer multiple comparisons test. In contrast to the carbachol results, DAMGO-stimulated G protein activation did not show any significant differences when analyzed as a function of hippocampal regions (Figs. $4 \mathrm{D}-\mathrm{F}$ ).

\section{DISCUSSION}

\section{Carbachol Differentially Activated G Proteins in CA1, CA3, and DG}

The present finding that the cholinergic agonist carbachol significantly increased $G$ protein activation in rat hippocampus (Figs. 2 and 3) is consistent with the significant increases in $\left[{ }^{35} \mathrm{~S}\right] \mathrm{GTP} \gamma \mathrm{S}$ binding in the vertical and horizontal limbs of the diagonal band of Broca, medial and lateral septum, and nucleus basalis/substantia innominata caused by carbachol (Douglas et al., 2004). The $\mathrm{G}$ protein data agree also with the longstanding hypothesis that cholinergic neurotransmission plays a major role in hippocampal function (Deutsch, 1971).

Cholinergic activation of $G$ proteins varied significantly across different regions of the hippocampus (Fig. 4). The differences in $G$ protein activation between DG and CA1 were small but statistically significant (Figs. 4B,C). Even small changes in cholinergic signaling can be physiologically relevant. For example, the hippocampus shares reciprocal connections with the prefrontal cortex (Beebe and Gozal, 2002) where even a $15 \%$ increase in acetylcholine (ACh) release causes a physiologically significant activation of the electroencephalogram (Douglas et al., 2002).

The Figure 4 data show that intermittent hypoxia and sustained hypoxia caused significantly lower carbachol-stimulated G protein activation in the DG than in the CA1. The present data do not address the mechanisms causing the lower level of $G$ protein activation in DG. This result is of interest in view of the continuous neurogenesis in the DG (Zhu et al., 2005; Christie and Cameron, 2006; Wiskott et al., 2006). The cyclic AMP response element binding protein (CREB) is critical for neurogenesis and hippocampal CREB can be modulated by hypoxia (Gozal et al., 2003). There might also be fewer muscarinic cholinergic receptors in the DG. The decreased $G$ protein activation in DG associated with hypoxia (Fig. 4) is consistent with previous studies showing that hypoxia disrupts rat sleep (Hamrahi et al., 2001) and with the finding that sleep deprivation causes decreased cell proliferation in rat DG (Guzmán-Marín et al., 2003).

\section{Hypoxia Did Not Alter Opioid-Induced Activation of Hippocampal G proteins}

$\mathrm{Mu}$ opioid receptors, similar to muscarinic cholinergic receptors, are coupled to $\mathrm{G}$ proteins and can be visualized using the $\left[{ }^{35}\right.$ S GTP $\gamma S$ assay (Sim et al., 1995; Capece et al., 1998b). The significant increase in $\left[{ }^{35} \mathrm{~S}\right] \mathrm{GTP} \gamma \mathrm{S}$ caused by DAMGO (Figs. 3D-F) provides a positive control for the activation of $\mathrm{G}$ proteins by carbachol (Figs. 3A-C). The hypothesis that hypoxia alters DAMGO-stimulated $G$ protein activation was drawn from previous evidence showing that mu opioid receptor activation of $\mathrm{G}$ proteins can change with experience. For example, chronic heroin administration causes a $61 \%$ decrease in DAMGO-stimulated $\left[{ }^{35} \mathrm{~S}\right] \mathrm{GTP} \gamma \mathrm{S}$ binding within hippocampus (Sim-Selley et al., 2000). The current results did not support the hypothesis that intermittent or sustained hypoxia altered activation of hippocampal $\mathrm{G}$ proteins by DAMGO.

\section{Acetylcholine, Sleep, and Hippocampal Function}

There is compelling evidence that ACh contributes to hippocampal-dependent learning and memory (Hasselmo and Schnell, 1994; Vizi and Kiss, 1998; Hasselmo, 1999; Hasselmo and McClelland, 1999; Rouse et al., 1999; van der Zee and Luiten, 1999; Rogers and Kesner, 2003) and ACh levels in the hippocampus increase during memory consolidation (Power et al., 2003). The view that sleep contributes to memory consolidation (Smith, 1985, 1996; Stickgold et al., 2001; Staba et al., 2002; Datta et al., 2004; Walker and Stickgold, 2006) is directly relevant to the current focus on cholinergic activation of hippocampal $\mathrm{G}$ proteins. Cholinergic neurotransmission is involved in generating rapid eye movement (REM) sleep (Lydic and Baghdoyan, 2005), hypoxia disrupts REM sleep in human (Ryan and Bradley, 2005) and rat (Hamrahi et al., 2001), and ACh release in the hippocampus increases during REM sleep (Marrosu et al., 1995). Basal forebrain neurons provide ACh to the hippocampus and $\mathrm{ACh}$ release in the basal forebrain is maximal during the REM phase of sleep (Vazquez and Baghdoyan, 2001). A memory consolidating role for sleep is also consistent with electrophysiological data from rat (Wilson and McNaughton, 1994) and human (Staba et al., 2002) documenting hippocampal CA1 place cell firing patterns during sleep that replicate discharge sequences previously recorded during wakefulness. In contrast to sleep facilitating learning, sleep deprivation leads to impaired executive control and poor performance on vigilance tasks (Decary et al., 2000; Horstmann et al., 2000). In rat, sleep deprivation impairs hippocampalmediated contextual learning (Ruskin et al., 2004) and selective REM sleep deprivation impairs learning of a spatial navigational task (Bjorness et al., 2005).

\section{Limitations and Conclusions}

The $\left[{ }^{35} \mathrm{~S}\right] \mathrm{GTP} \gamma \mathrm{S}$ assay was limited to a single concentration of carbachol (1 $\mathrm{mM})$ demonstrated by previous studies to be ideal for detecting $G$ proteins activated by muscarinic cholinergic receptors (Capece et al., 1998b; DeMarco et al., 2003; Douglas et al., 2004). Likewise, the present study used a single concentration of DAMGO $(3 \mu \mathrm{M})$, shown previously to activate $\mathrm{G}$ proteins by mu opioid receptors (Capece et al., 1998b; DeMarco et al., 2003). There are no purely subtype selective muscarinic agonists and the present study permits no conclusions regarding subtypes of muscarinic cholinergic receptors mediating the response to carbachol. The exposure to hypoxia in the present study was limited to a single time interval of 14 
days. The ability of hypoxia to modulate hippocampal G protein activation may vary as a function of duration of hypoxic exposure. There are further limitations in the inability of the present study to specify the type of $G$ proteins activated by carbachol or DAMGO. In general, the kinetics of the $\left[{ }^{35} \mathrm{~S}\right] \mathrm{GTP} \gamma \mathrm{S}$ assay favor activation of inhibitory $\mathrm{G}$ proteins (Harrison and Traynor, 2003; Bernard et al., 2005, 2006).

In spite of these limitations, the $\left[{ }^{35} \mathrm{~S}\right] \mathrm{GTP} \gamma \mathrm{S}$ assay has two major advantages for studies of hippocampus (Sim-Selley et al., 2000; Hong and Werling, 2001). First, this assay provides the unique ability to localize $G$ proteins while preserving brain anatomy (Harrison and Traynor, 2003; Bernard et al., 2005). Thus, the colorized autoradiograms of Figure 2 precisely localize activated $G$ proteins within the CA1, CA3, and DG regions of rat hippocampus. Second, by subtracting nonspecific binding from total binding, the assay provides a quantitative measure of specific $\left[{ }^{35} \mathrm{~S}\right] \mathrm{GTP} \gamma \mathrm{S}$ binding (Figs. 3 and 4). These two features made the $\left.{ }^{35} \mathrm{~S}\right] \mathrm{GTP} \gamma \mathrm{S}$ assay ideal for testing the hypothesis that hypoxia alters $G$ protein activation in the hippocampus.

In conclusion, three novel findings emerge from this study. First, compared to basal levels of $G$ protein activation, the cholinergic agonist carbachol and the mu opioid agonist DAMGO significantly activated $G$ proteins in the CA1, CA3, and the DG regions of the hippocampus. Second, the magnitude of G protein activation by DAMGO was greater than activation caused by carbachol, and $G$ protein activation by DAMGO was not altered by hypoxia. Third, quantifying agonist activation of $\mathrm{G}$ proteins as a function of hippocampal region showed that intermittent hypoxia and sustained hypoxia caused significantly lower levels of $\mathrm{G}$ protein activation by carbachol in the DG than in CA1. These results suggest the potential for hypoxia to alter hippocampal function by blunting the cholinergic activation of $G$ proteins within the DG.

\section{Acknowledgments}

We thank D. Ignasiak, S. Jiang, and M.A. Norat for expert assistance. For statistical input we thank K. Welch and the University of Michgan Center for Statistical Consultation and Research.

\section{REFERENCES}

Beebe DW. 2005. Neurobehavioral effects of obstructive sleep apnea: An overview and heuristic model. Curr Opin Pulm Med 11:494-500.

Beebe DW, Gozal D. 2002. Obstructive sleep apnea and the prefrontal cortex: towards a comprehensive model linking nocturnal upper airway obstruction to daytime cognitive and behavioral deficits. J Sleep Res 11:1-16.

Bernard R, Lydic R, Baghdoyan HA. 2005. Hypocretin receptor-activated $G$ proteins revealed by $\left[{ }^{35} \mathrm{~S}\right] \mathrm{GTP} \gamma \mathrm{S}$ autoradiography. In: Nishino S, Sakurai T, editors. The Orexin/Hypocretin System: Physiology and Pathophysiology. Totowa, NJ: Humana Press. pp 83-96.

Bernard R, Lydic R, Baghdoyan HA. 2006. Hypocretin (orexin) receptor subtypes differentially enhance acetylcholine release and activate $G$ protein subtypes in rat pontine reticular formation. J Pharmacol Exp Ther 317:163-171.
Bjorness TE, Riley BT, Tysor MK, Poe GR. 2005. REM restriction persistently alters strategy used to solve a spatial task. Learn Mem 12:352-359.

Capece ML, Baghdoyan HA, Lydic R. 1998a. Carbachol stimulates $\left[{ }^{35} \mathrm{~S}\right]$ guanylyl $5^{\prime}$-( $\gamma$-thio)-triphosphate binding in rapid eye movement sleep-related brainstem nuclei of rat. J Neurosci 18:3779-3785.

Capece ML, Baghdoyan HA, Lydic R. 1998b. Opioids activate G proteins in REM sleep-related brain stem nuclei of rat. Neuroreport 9:3025-3028.

Caulfield MP, Birdsall NJM. 1998. International union of pharmacology. XVII. Classification of muscarinic acetylcholine receptors. Pharmacol Rev 50:279-290.

Christie BR, Cameron HA. 2006. Neurogenesis in the adult hippocampus. Hippocampus 16:199-207.

Colom LV, Sassif-Caudarella S, Dickson CT, Smythe JW, Bland BH. 1991. In vivo intrahippocampal microinfusion of carbachol and bicuculline induces theta-like oscillations in the septally deafferented hippocampus. Hippocampus 1:381-390.

Corbett AD, Henderson G, McKnight AT, Paterson SJ. 2006. 75 years of opioid research: The exciting but vain quest for the Holy Grail. Br J Pharmacol 147 (Suppl 1):S153-S162.

Crain BJ, Chang KJ, McNamara JO. 1986. Quantitative autoradiographic analysis of mu and delta opioid binding sites in the rat hippocampal formation. J Comp Neurol 246:170-180.

Datta S, Mavanji V, Ulloor J, Patterson EH. 2004. Activation of phasic pontine-wave generator prevents rapid eye movement sleep deprivation-induced learning impairment in the rat: A mechanism for sleep-dependent plasticity. J Neurosci 24:1416-1427.

Decary A, Rouleau I, Montplaisir J. 2000. Cognitive deficits associated with sleep apnea syndrome: A proposed neuropsychological test battery. Sleep 23:369-381.

DeMarco GJ, Baghdoyan HA, Lydic R. 2003. Differential cholinergic activation of $\mathrm{G}$ proteins in rat and mouse brainstem: Relevance for sleep and nociception. J Comp Neurol 457:175-184.

Deutsch JA. 1971. The cholinergic synapse and the site of memory. Science 174:788-794.

Douglas CL, Baghdoyan HA, Lydic R. 2002. Prefrontal cortex acetylcholine release, EEG slow waves, and spindles are modulated by M2 autoreceptors in C57BL/6J mouse. J Neurophysiol 87:28172822.

Douglas CL, DeMarco GJ, Baghdoyan HA, Lydic R. 2004. Pontine and basal forebrain cholinergic interaction: Implications for sleep and breathing. Respir Physiol Neurobiol 143:251-262.

Drake CT, Milner TA. 2002. Mu opioid receptors are in discrete hippocampal interneuron subpopulations. Hippocampus 12:119-136.

Dunwiddie T, Mueller A, Palmer M, Stewart J, Hoffer B. 1980. Electrophysiological interactions of enkephalins with neuronal circuitry in the rat hippocampus. I. Effects on pyramidal cell activity. Brain Res 184:311-330.

Engleman H, Joffe D. 1999. Neuropsychological function in obstructive sleep apnoea. Sleep Med Rev 3:59-78.

Goldbart A, Cheng ZJ, Brittian KR, Gozal D. 2003a. Intermittent hypoxia induces time-dependent changes in the protein kinase $\mathrm{B}$ signaling pathway in the hippocampal CA1 region of the rat. Neurobiol Dis 14:440-446.

Goldbart A, Row BW, Kheirandish L, Schurr A, Gozal E, Guo SZ, Payne RS, Cheng Z, Brittian KR, Gozal D. 2003b. Intermittent hypoxic exposure during light phase induces changes in cAMP response element binding protein activity in the rat CA1 hippocampal region: Water maze performance correlates. Neuroscience 122:585-590.

Gozal D, Daniel JM, Dohanich GP. 2001a. Behavioral and anatomical correlates of chronic episodic hypoxia during sleep in the rat. J Neurosci 21:2442-2450.

Gozal E, Row BW, Schurr A, Gozal D. 2001b. Developmental differences in cortical and hippocampal vulnerability to intermittent hypoxia in the rat. Neurosci Lett 305:197-201. 
Gozal E, Gozal D, Pierce WM, Thongboonkerd V, Scherzer JA, Sachleben LR, Jr., Brittian KR, Guo SZ, Cai J, Klein JB. 2002. Proteomic analysis of CA1 and CA3 regions of rat hippocampus and differential susceptibility to intermittent hypoxia. J Neurochem 83:331-345.

Gozal D, Row BW, Gozal E, Kheirandish L, Neville JJ, Brittian KR, Sachleben LR Jr, Guo SZ. 2003. Temporal aspects of spatial task performance during intermittent hypoxia in the rat: Evidence for neurogenesis. Eur J Neurosci 18:2335-2342.

Greenberg HE, Sica AL, Scharf SM, Ruggiero DA. 1999. Expression of $\mathrm{c}$-fos in the rat brainstem after chronic intermittent hypoxia. Brain Res 816:638-645.

Guzmán-Marín R, Suntsova N, Steward DR, Gong H, Szymusiak R, McGinty D. 2003. Sleep deprivation reduces proliferation of cells in the dentate gyrus of the hippocampus in rats. J Physiol 549:563-571.

Hambrecht VS, Vlisides PE, Row BW, Gozal D, Baghdoyan HA, Lydic R. 2006. Hypoxia alters $G$ protein activation by carbachol in the hippocampus of Sprague-Dawley rat. Neuroscience Meeting Planner. Atlanta, GA: Society for Neuroscience, Program No. 157.13.

Hamrahi H, Stephenson R, Mahamed S, Liao KS, Horner RL. 2001. Regulation of sleep-wake states in response to intermittent hypoxic stimuli applied only in sleep. J Appl Physiol 90:2490-2501.

Harrison C, Traynor JR. 2003. The $\left[{ }^{35}\right.$ S GTP $\gamma S$ binding assay: Approaches and applications in pharmacology. Life Sci 74:489508.

Hasselmo ME. 1999. Neuromodulation: Acetylcholine and memory consolidation. Trends Cogn Sci 3:351-359.

Hasselmo ME, McClelland JL. 1999. Neural models of memory. Curr Opin Neurobiol 9:184-188.

Hasselmo ME, Schnell E. 1994. Laminar selectivity of the cholinergic suppression of synaptic transmission in rat hippocampal region CA1: Computational modeling and brain slice physiology. J Neurosci 14:3898-3914.

Hong W, Werling L. 2001. Lack of effect by $\sigma$ ligands on neuropeptide Y-induced G-protein activation in rat hippocampus and cerebellum. Brain Res 901:208-218.

Horstmann S, Hess CW, Bassetti C, Gugger M, Mathis J. 2000. Sleepiness-related accidents in sleep apnea patients. Sleep 23:383389.

Lydic R, Baghdoyan HA. 2005. Sleep, anesthesiology, and the neurobiology of arousal state control. Anesthesiology 103:1268-1295.

Mansour A, Khachaturian H, Lewis ME, Akil H, Watson SJ. 1987. Autoradiographic differentiation of mu, delta, and kappa opioid receptors in the rat forebrain and midbrain. J Neurosci 7:24452464.

Marrosu F, Portas C, Mascia MS, Casu MA, Fa M, Giagheddu M, Imperato A, Gessa GL. 1995. Microdialysis measurement of corti$\mathrm{cal}$ and hippocampal acetylcholine release during sleep-wake cycle in freely moving cats. Brain Res 671:329-332.

Matsuoka Y, Kitamura Y, Fukunaga R, Shimohama S, Nabeshima T, Tooyama I, Kimura H, Taniguchi T. 1997. In vivo hypoxiainduced neuronal damage in dentate gyrus of rat hippocampus: Changes in NMDA receptors and the effect of MK-801. Neurochem Int 30:533-542.

Mayer JH, Henriksen SJ. 1995. Electrophysiological effects of muselective opioids on hilar neurons in the hippocampus in vivo. Hippocampus 5:557-568.

Mayer JH, Steffensen SC, Henriksen SJ. 1994. Electrophysiological effects of selective opioid agonists on spontaneous and evoked neuronal activity in the dentate gyrus of the hippocampus in vivo. Neuropharmacology 33:963-975.

Ninomiya $H$, Taniguchi T, Fujiwara M, Shimohama S, Kameyama M. 1989. Effect of in vivo exposure to hypoxia on muscarinic cholinergic receptor-coupled phosphoinositide turnover in the rat brain. Brain Res 482:109-121.
Paxinos G, Watson C. 1998. The Rat Brain in Stereotaxic Coordinates. San Diego, CA: Academic Press.

Power AE, Vazdarjanova A, McGaugh JL. 2003. Muscarinic cholinergic influences in memory consolidation. Neurobiol Learn Mem 80:178-193.

Rogers JL, Kesner RP. 2003. Cholinergic modulation of the hippocampus during encoding and retrieval. Neurobiol Learn Mem 80:332-342.

Rouse ST, Marino MJ, Potter LT, Conn PJ, Levey AI. 1999. Muscarinic receptor subtypes involved in hippocampal circuits. Life Sci 64:501-509.

Ruskin DN, Liu C, Dunn KE, Bazan NG, LaHoste GJ. 2004. Sleep deprivation impairs hippocampus-mediated contextual learning but not amygdala-mediated cued learning in rats. Eur J Neurosci 19:3121-3124.

Row BW, Liu R, Xu W, Kheirandish L, Gozal D. 2003. Intermittent hypoxia is associated with oxidative stress and spatial learning deficits in the rat. Am J Respir Crit Care Med 167:15481553 .

Ryan CM, Bradley TD. 2005. Pathogenesis of obstructive sleep apnea. J Appl Physiol 99:2440-2450.

Satoh M, Kaneko S. 1994. Involvement of postsynaptic G-proteins in hippocampal long-term potentiation. Rev Neurosci 5:1-9.

Schiff SJ, Somjen GG. 1985. Hyperexcitability following moderate hypoxia in hippocampal tissue slices. Brain Res 337:337-340.

Shamsuzzaman ASM, Gersh BJ, Somers VK. 2003. Obstructive sleep apnea. JAMA 290:1906-1914.

Siggins GR, Zieglgansberger W. 1981. Morphine and opioid peptides reduce inhibitory synaptic potentials in hippocampal pyramidal cells in vitro without alteration of membrane potential. Proc Natl Acad Sci USA 78:5235-5239.

Sim LJ, Selley DE, Childers SR. 1995. In vitro autoradiography of receptor-activated $\mathrm{G}$ proteins in rat brain by agonist-stimulated guanylyl $5^{\prime}-\left[\gamma-\left[{ }^{35} S\right]\right.$ thio $]$-triphosphate binding. Proc Natl Acad Sci USA 92:7242-7246.

Sim LJ, Selley DE, Childers SR. 1997. Autoradiographic visualization in brain of receptor-G protein coupling using $\left[{ }^{35} \mathrm{~S}\right] \mathrm{GTP} \gamma \mathrm{S}$ binding. Methods Mol Biol 83:117-132.

Sim-Selley LJ, Selley DE, Vogt LJ, Childers SR, Martin TJ. 2000. Chronic heroin self-administration desensitizes mu opioid receptoractivated G-proteins in specific regions of rat brain. J Neurosci 20:4555-4562.

Smith CT. 1985. Sleep states and learning: A review of the animal literature. Neurosci Biobehav Rev 9:157-168.

Smith CT. 1996. Sleep states, memory processes and synaptic plasticity. Behav Brain Res 78:49-56.

Staba RJ, Wilson CL, Fried I, Engel J. 2002. Single neuron burst firing in the human hippocampus during sleep. Hippocampus 12:724-734.

Stickgold R, Hobson JA, Fosse R, Fosse M. 2001. Sleep, learning, and dreams: Off-line memory reprocessing. Science 294:10521057.

Svodoba KR, Adams CE, Lupica CR. 1999. Opioid receptor subtype expression defines morphologically distinct classes of hippocampal interneurons. J Neurosci 19:85-95.

Tanase D, Martin WA, Baghdoyan HA, Lydic R. 2001. G protein activation in rat ponto-mesencephalic nuclei is enhanced by combined treatment with a mu opioid and an adenosine $A_{1}$ receptor agonist. Sleep 24:52-62.

Tempel A, Zukin RS. 1987. Neuroanatomical patterns of the mu, delta, and kappa opioid receptors of rat brain as determined by quantitative in vitro autoradiography. Proc Natl Acad Sci USA 84:4308-4312.

van der Zee EA, Luiten PG. 1999. Muscarinic acetylcholine receptors in the hippocampus, neocortex and amygdala: A review of immunocytochemical localization in relation to learning and memory. Prog Neurobiol 58:409-471. 
Vazquez J, Baghdoyan HA. 2001. Basal forebrain acetylcholine release during REM sleep is significantly greater than during waking. Am J Physiol 280:R598-R601.

Vizi ES, Kiss JP. 1998. Neurochemistry and pharmacology of the major hippocampal transmitter systems: Synaptic and nonsynaptic interactions. Hippocampus 8:566-607.

Walker MP, Stickgold R. 2006. Sleep, memory, and plasticity. Annu Rev Psychol 57:139-166.

Watson SJ, Khachaturian H, Akil H, Coy DH, Goldstein A. 1982. Comparison of the distribution of dynorphin systems and enkephalin systems in brain. Science 218:1134-1136.

Wilson MA, McNaughton BL. 1994. Reactivation of hippocampal ensemble memories during sleep. Science 265:676-679.

Wiskott L, Rasch MJ, Kempermann G. 2006. A functional hypothesis for adult hippocampal neurogenesis: Avoidance of catastrophic interference in the dentate gyrus. Hippocampus 16:329-343.
Yamaoka Y, Shimohama S, Kimura J, Fukunaga R, Taniguchi T. 1993. Neuronal damage in the rat hippocampus induced by in vivo hypoxia. Exp Toxicol Pathol 45:205-209.

Young T, Palta M, Dempsey J, Skatrud J, Weber S, Badr S. 1993. The occurrence of sleep-disordered breathing among middle-aged adults. N Engl J Med 328:1230-1235.

Zhao P, Xue J, Gu XQ, Haddad GG, Xia Y. 2005. Intermittent hypoxia modulates $\mathrm{Na}^{+}$channel expression in developing mouse brain. Int J Dev Neurosci 23:327-333.

Zhu LL, Zhao T, Li HS, Zhao H, Wu LY, Ding AS, Fan WH, Fan M. 2005. Neurogenesis in the adult rat brain after intermittent hypoxia. Brain Res 1055:1-6.

Zieglgansberger W, French ED, Siggins GR, Bloom FE. 1979. Opioid peptides may excite hippocampal pyramidal neurons by inhibiting adjacent inhibitory interneurons. Science 205:415-417. 